\title{
Effects of alcohol during secondary neurulation in chick embryos
}

\section{Alkolün tavuk embriyolarında sekonder nörilasyon üzerine etkileri}

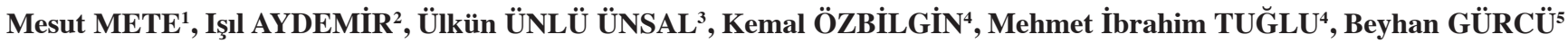 \\ ${ }^{1}$ Manisa Celal Bayar Üniversitesi Tıp Fakültesi Nöroșirürji Ana Bilim Dalı, Manisa \\ ${ }^{2}$ Ömer Halisdemir Üniversitesi Tıp Fakültesi Histoloji Embriyoloji Ana Bilim Dalı, Niğde \\ ${ }^{3}$ Koç Üniversitesi Tıp Fakültesi Nöroşirürji Ana Bilim Dalı, İstanbul \\ ${ }^{4}$ Manisa Celal Bayar Üniversitesi Tip Fakültesi Histoloji Embriyoloji Ana Bilim Dall, Manisa \\ ${ }^{5}$ Manisa Celal Bayar Fen Edebiyat Fakültesi, Biyoloji Ana Bilim Dalı, Manisa
}

\begin{abstract}
Objective: Alcohol continues to be consumed even though its harmful effecs are well established. One of the most common damage of alcohol consumption is fetal alcohol syndrome, characterized by craniofacial anomalies, cardiac anomalies and neural tube defects. Therefore, understanding the molecular mechanisms underlying the alcohol-induced toxicity that occur with time and dose dependent manner is very important. , Most of the studies in order to understand the effects of alcohol have been carried out on early neurulation, however its effects on late neurulation are still unknown. Therefore in this study, effects of alcohol on secondary neurulation were investigated in chick embryos.

Methods: Leghorn breed of embryonic chicken eggs were used. At $50 \mathrm{~h}$ of incubation, 100 $\mu \mathrm{L} 50 \%$ ethanol solution was injected. Depending on the period of exposure to alcohol, varying degrees of pathological disorders were detected in E3, E7 and E10 days.

Results: Developmental delay, structural abnormalities, morphological abnormalities in the heart and face and especially presence of two spinal cord cavities were found. In addition, we also detected delays in the closure of the neural tube, cellular deformities and the structural abnormalities in notochord. While eNOS, iNOS, and TUNEL levels increased, while laminin levels decreased.

Conclusion: In this study during late development, significant alcohol-induced morphological and histopathological changes were observed. We also determined Increased level of oxidative stress caused by alcohol was accompanied with the changes in matrix composition. Better understanding of these mechanisms which affect the cell behavior is important and will allow learning of harmful effects of alcohol.
\end{abstract}

Keywords: Alcohol, neural tube defect, secondary neurulation

\section{öz}

Amaç: Alkol, zararları iyi bilinmesine rağmen, tüketilmeye devam edilmektedir. Alkol tüketiminin en yaygın hasarlarından biri kraniofasial anomaliler, kardiyak anomaliler ve nöral tüp kusurlarıyla karakterize fetal alkol sendromudur. Bu nedenle, alkole bağlı toksisitenin altında yatan, zaman ve doza bağlı olarak ortaya çıkan moleküler mekanizmaları anlamak çok önemlidir. Alkolün etkilerini anlamak için, yapılan çalışmaların çoğu erken nörilasyon üzerine yapılmıştır. Ancak, geç nörilasyon üzerindeki etkileri halen bilinmemektedir. Bu nedenle bu çalışmada, civciv embriyolarında alkolün sekonder nörilasyon üzerindeki etkileri araştırılmıştır.

Yöntem: Leghorn cinsi embriyonik tavuk yumurtalarını kullanıldı. Kuluçka işleminin 50. saatinde, $100 \mathrm{uL} \% 50$ etanol çözeltisi enjekte edildi. Alkole maruz kalma süresine bağglı olarak, E3, E7 ve E10 günlerinde değişik derecelerde patolojik bozukluk belirlendi.

Bulgular: Gelişim geriliği, yapısal anomaliler, kalp ve yüzdeki morfolojik anomaliler ve özellikle iki spinal kord boşluğunun varlığı saptandı. Buna ek olarak, nöral tüpün kapanmasında gecikmeler, hücresel deformasyonlar ve notokordun oluşumunda anomaliler belirlendi. ENOS, iNOS ve TUNEL düzeyleri artarken, laminin önemli ölçüde azaldı̆̆ görüldü.

Sonuç: Bu çalışmada geç gelişme döneminde alkolün yol açtığı morfolojik ve histopatolojik değişiklikler gözlendi. Alkolden kaynaklanan oksidatif stres düzeyindeki artı̧̧a matriks kompozisyonundaki değişiklikler eşlik etti. Hücre davranışını etkileyen bu mekanizmaların daha iyi anlaşılması önemli olup, alkolün zararlı etkilerinin öğrenilmesine izin verecektir.

Anahtar kelimeler: Alkol, nöral tüp defekti, sekonder nörilasyon

Alındığı tarih: 02.11.2017

Kabul tarihi: 05.11.2017

Yazışma adresi: Yrd. Doç. Dr. Mesut Mete, Manisa Celal Bayar Üniversitesi Tıp Fakültesi Nöroşirürji Ana Bilim Dalı, 50200 - Manisa - Türkiye e-mail: dr.mmete@hotmail.com 


\section{INTRODUCTION}

Neural tube is formed by primary neurulation ventrally and secondary neurulation dorsally at the structural overlap between the caudal end of the neural plate and cranial end of the tail bud ${ }^{(1)}$. Full and complete neurulation is very important for the development of brain and spinal cord. Neurulation has to be successfully completed for a normal structural and functional development of various tissues and organs associated with the central nervous system. It is known that some diseases and physical abnormalities can occur in later stages of life due to exposure to agents with teratogenic effects during neural tube development ${ }^{(2)}$. Alcohol, which is a chemical agent, can easily pass the placenta barrier, reach the fetus and cause developmental abnormalities such as seen in fetal alcohol syndrome (FAS). FAS was first described by Jones and Smith in 1973 and characterized by prenatal and postnatal growth retardation, craniofacial anomalies, central nervous system dysfunction, and anomalies involving the musculoskeletal system, heart, eyes and kidneys as reduced proliferation, disrupted DNA and protein synthesis, and apoptosis contribute to the effects of alcohol on growth retardation ${ }^{(2,3)}$. However, the exact molecular pathways leading to FAS are stil unknown.

$\mathrm{NO}$ is a potent molecule that plays an important role in intra-cellular and inter-cellular messaging systems ${ }^{(4)}$. It exhibits antioxidant effects via detoxification of reactive oxygen species (ROS). Studies on ROS have argued that increased oxidative stress disrupted the functions of the mitochondria, resulting in neuronal disorders and caused embryonic malformations characterized by high levels of apoptosis ${ }^{(5)}$. Peunova et al. ${ }^{(6)}$ argued that NO altered the cell behavior via kinases, cytoskeleton, scaffold proteins and epigenetics. Ron and Messing ${ }^{(7)}$ also lend support to Peunova et al. ${ }^{(6)}$ by showing that alcohol caused NTD through similar pathways.

During the development of the neural tube, mesenchymal cells become polarized to form the neural tube epithelium and the basement membrane is formed by accumulation of laminin and fibrocentin especially from large glycoproteins. Laminin is invol- ved in adhesion of the cells to the basement membrane. Further, it communicates with intracellular skeleton and guides the cellular function. Neuronal NO synthase (nNOS; NOS-1) and endothelial NO synthase (eNOS; NOS-3) are constitutively expressed and do not vigorously respond to extracellular stimulation. In contrast, inducible NO synthase (iNOS; NOS-2) actively responds to extracellular changes, with a marked upregulation in expression and activity of laminin. It has been thought that the presence of laminin in the neural tube and mesenchyma was not altered much during secondary neurulation and that it was there to form a boundary. Fibronectin, on the other hand, has been found in abundance especially in regions where neural crest cells were populated. It has been shown that mesenchymal cavitations which occur during neurulation but not related to neural tube contain copious amounts of fibronectin which has been considered as an adjunct to cell-to-cell adhesion ${ }^{(8)}$. When the oxidative stress is increased in biological tissues, the cells cannot fulfill detoxification, resulting in destruction of the cytoskeleton, reduction in adhesion capacity, cell degeneration and, subsequently, cell death ${ }^{(9)}$. Loss of cell matrix and adhesion capability affects cell cycle, inhibits growth and induces apoptosis ${ }^{(5)}$.

Even though there is a debate as to whether secondary neurulation in chick is similar to posterior neural tube development in humans, it is highly possible that similar molecules are used. Defects in this region are also believed to occur similarly ${ }^{(10)}$. It has been shown that laminin is present in mesenchymalepithelial transition zones throughout $\mathrm{HH}-18$ and 20 stages and that it provides polarization of cells there and contributed to the development of the basement membrane. This environment with these cells produces secondary neurulation ${ }^{(11)}$. However, exact effect of laminin in this period is yet to be established.

Neural tube defect is one of the central nervous system disorders that cause very important social, economical and medical problems. Although there have been many studies on primary neurulation, studies on the function of secondary neurulation and caudal region are limited. In the present study, effects of ethanol application on secondary neurulation in 
chick embryos were investigated. Possible developmental anomalies and mechanisms underlying these anomalies have been investigated with e-NOS and i-NOS staining with regard to oxidative stress, laminin $\alpha 1$ with regard to matrix molecules and TUNEL staining with regard to apoptosis.

\section{MATERIAL and METHODS}

We used Leghorn breed of embryonated chicken eggs which were supplied by Republic of Turkey Ministry of Agriculture and Rural Affairs, Bornova Veterinary Control and Research Institute. Eggs were divided into three groups (each $\mathrm{n}=10$ ) as Control, Sham and ethanol treated groups. They were incubated in about $60-80 \%$ humidified atmosphere at $37,5^{\circ} \mathrm{C}$. At $50^{\text {th }} \mathrm{h}$ of incubation which corresponds to HH-stage-13-14 ${ }^{(12)}$ they were rinsed with $70 \%$ ethanol and a piece of plastic tape was placed close to the air cavity of the eggs, and a small hole was opened for injections. Hundred $\mu \mathrm{L} 50 \%$ ethanol solution and $100 \mu \mathrm{L}$ saline (sham) were injected under the embryo discs with a 30-gauge syringe while the control group did not undergo any procedure. Then, in all the groups, the eggs were closed with a sterile tape. Samples were taken at $1^{\text {st }}$ (E3 days group), $5^{\text {th }}$ (E7 days group) and $8^{\text {th }}$ (E10 days group) days after the injection. Embryos were fixed in $10 \%$ buffered formalin solution, dehydrated in graduated ethyl alcohol and were passed through xylene (Riedel-de Haën, Germany) and embedded in paraffin (Isolab, U.K.) blocks. All samples of $5 \mu \mathrm{m}$-thick serial sections were taken on normal and poly-1-lysine coated slides (Sigma, U.K.). Sections were stained with Mayer's heamatoxylineosin (HE) (Sigma U.K.) to demonstrate the histological structure. Also eNOS (RS-654, CA, USA), iNOS (RS-651, CA, USA), laminin $\alpha 1$ (SC-5582, CA, USA) and TUNEL (Millipore-s7101, CA, USA) immunohistochemistry stainings were performed in order to detect possible effects of proteins thought to be in the mechanism ${ }^{(15)}$. Sections were viewed under Leica (DM 4000B) light-field microscope at various magnifications and images were acquired by Olympus (DP 71) camera.

Immunohistochemistry: The sections were incu- bated at $60^{\circ} \mathrm{C}$ overnight then dewaxed in xylene for 30 minutes. After rehydrating through a decreasing series of ethanols, sections were washed in distilled water and PBS for 10 minute. They were then treated with $2 \%$ trypsin in $50 \mathrm{mM}$ Tris buffer $(\mathrm{pH} \mathrm{7.5)}$ at $37^{\circ} \mathrm{C}$ for 15 minutes and washed again with PBS. Sections were delineated using a Dako pen (Dako, Glostrup, Denmark) and incubated in a solution of $3 \% \mathrm{H}_{2} \mathrm{O}_{2}$ for 15 minutes to inhibit endogenous peroxidase activity. After this procedure, sections were washed with PBS and incubated with primary antibodies to iNOS (1:100 dilution; Zymed, 61-7700 South San Francisco, CA) and eNOS (1:200 dilution; Biomol, SA-258, Hamburg, Germany) for 18 hours. After washing, the sections were incubated with biotinylated $\mathrm{IgG}$ and then with streptavidin-peroxidase conjugate (Histostain-Plus Bulk Kits; Zymed, South San Francisco, CA, according to kit instructions). Then, the sections were washed with PBS, incubated with a solution containing 3-amino-9-ethylcarbazole (AEC) for 5 minutes to visualize immunolabelling, and finally counterstained with Mayer's haematoxylin. The negative controls were treated as above, except incubation with the primary antibody was replaced by incubation with rabbit IgG or mouse IgG. Control samples were processed in the same manner except that the primary antibodies were omitted. All dilutions and thorough washes between stages were performed using PBS unless otherwise stated ${ }^{(14)}$.

TUNEL method: An in situ apoptosis detection kit (Dead End Colorimetric) TUNEL (terminal deoxynucleotidyl transferase-mediated dUTP nick endlabelled System, Promega) was used to detect apoptosis and all reagents listed below were included, unless otherwise stated. The sections were deparaffinized in xylene, rehydrated as above, incubated with $20 \mu \mathrm{g} / \mathrm{ml}$ proteinase $\mathrm{K}$ for 10 minutes, and rinsed in distilled water. Endogenous peroxidase activity was inhibited by incubation with $3 \%$ hydrogen peroxide $\left(\mathrm{H}_{2} \mathrm{O}_{2}\right)$ for 5 minutes. The sections were then incubated with equilibration buffer for 10-15 seconds and TdT enzyme, and prepared according to kit instructions, in a humidified atmosphere, at $37^{\circ} \mathrm{C}$, for 60 minutes. They were subsequently placed in prewarmed working strength stop/wash buffer at room 
temperature for 10 minutes, and incubated with antistreptavidin-peroxidase, at a 1:500 dilution in PBS, for 45 minutes. Each step was separated by careful washing in PBS. Labelling was revealed using DAB/ $\mathrm{H}_{2} \mathrm{O}_{2}$, nuclei were counterstained with Mayer's haematoxylin, and sections were mounted as described previously ${ }^{(15)}$.

Statistical evaluation: Immunohistochemistry was evaluated semiquantitatively utilizing the $\mathrm{H}$-score technique by a histologist with blinded manner. $\mathrm{H}$-score (0-300) was calculated by multiplying staining intensity $(0$, negative; 1 , weak; 2 , moderate; 3 , strong) with the positively stained area $(0-100 \%)$. For TUNEL staining, each section was counted for 100 cells from randomly chosen fields by a histologist with blinded manner. The percentage of apoptotic cells to total number of cells was indicated as apoptotic index ${ }^{(16)}$.

\section{RESULTS}

Embryos from the shams and alcohol administration groups were observed and photographed both macroscopically and microscopically. There was no infected embryos among these samples. Numbers and percentages of normal and abnormal embryos after incubation with physiological saline and alcohol $\% 50$ are seen in Table 1 Macroscopic evaluation: Growth retardation, deformations in the heart and limbs, deterioration in vesicles in brain regions, flattening of the head and distortions in vascularization were observed in E3 embryos . In addition, vascular disorders that affect the embryos were observed. Growth retardation in all organs, the small head, con-

Table 1. Numbers and percentages of normal and abnormal embryos after incubation with physiological saline and.

\begin{tabular}{|c|c|c|c|c|c|}
\hline \multicolumn{2}{|l|}{ Groups } & $\begin{array}{c}\text { Embryos } \\
\text { n }(\%)\end{array}$ & $\begin{array}{l}\text { Lethal } \\
\text { n (\%) }\end{array}$ & $\begin{array}{c}\text { Observed } \\
\text { n }(\%)\end{array}$ & \multirow{2}{*}{$\begin{array}{c}\begin{array}{c}\text { Growth } \\
\text { Reterdation } \\
\mathbf{n}(\%)\end{array} \\
0(0)\end{array}$} \\
\hline Sham & $\begin{array}{c}3^{\text {th }}, 7^{\text {th }} \text { and } \\
10^{\text {th }} \text { days }\end{array}$ & $10(100 \%)$ & $0(0)$ & $10(100 \%)$ & \\
\hline $50 \%$ & $3^{\text {th }}$ days & $10(100 \%)$ & $0(0)$ & $10(100 \%)$ & $8(80 \%)$ \\
\hline Alcohol & $7^{\text {th }}$ days & $10(100 \%)$ & $3(30 \%)$ & $7(70 \%)$ & $6(85 \%)$ \\
\hline & $10^{\text {th }}$ days & $10(100 \%)$ & $7(70 \%)$ & $3(30 \%)$ & $3(100 \%)$ \\
\hline
\end{tabular}

tour distortion and flattening in the facial region were observed in E7 embryos. Growth retardation, disturbances in the body symmetry, deformation in the layer and pigmentation of the eyes were observed in E10 embryos (Figure 1).

Microscopic evaluation: HE staining in E3 day group (Stage 20) of sham group as control group; medullary cord and ventricular layers which were formed by neuroepitelial cells, dermomyotome, sclerotome and notochord were seen. The surface ecto-

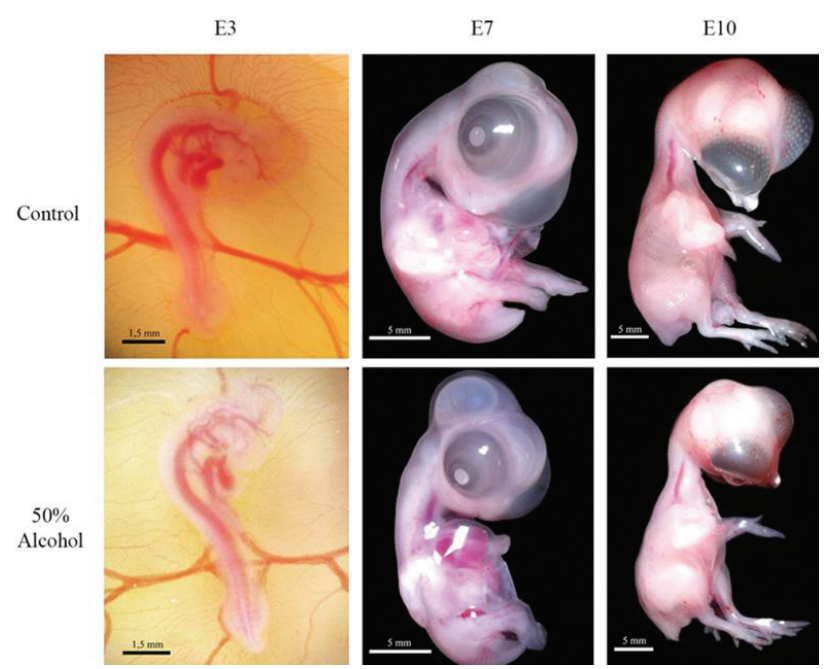

Figure 1. Compared to sham group, ethanol administration caused growth retardation, reduction of the vascularization and, in particular, structural abnormalities of the heart or head in E3 days. In E7 days, brain vesicles expansion, eye and retinal pigmentation abnormalities can be considered. In E10 days, moderate growth retardation and disorders were observed.

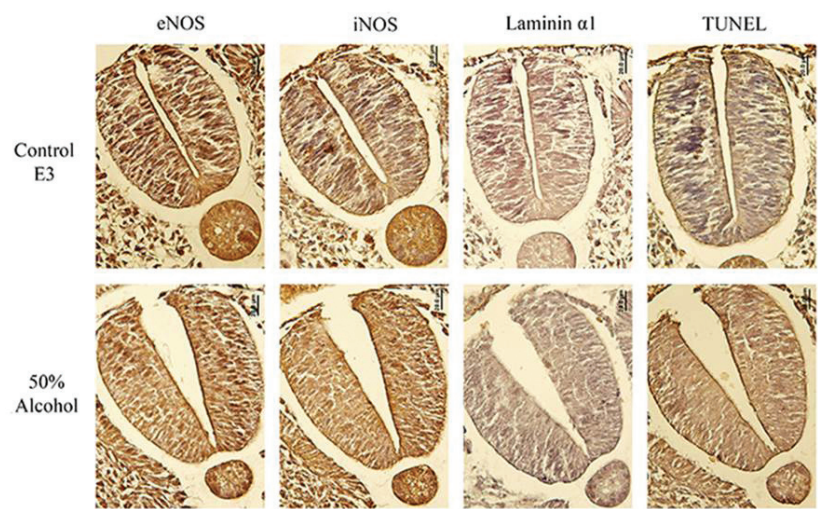

Figure 2. In Sham group, normally closed neural tube, normal surface ectoderm and neural ectoderm and notochord were seen. However, in E3 days ethanol administration group, reduction in the notochord and open neural tube were detected. Bar: 20 um. 
derm and the neural tube was properly settled, the cavity was formed with a central channel and surrounding mesenchymal cells with the normal appearance was established and also neural tube closure was observed. However, in alcohol treated group , delay in neural tube closure, notochord shrinking, reduction in neuroepithelial thickness and differences in the cell shape and layout were observed. Although in sham group, normal basal level of e-NOS and i-NOS staining were present, these staining were more frequently seen in alcohol treated group. We observed that e-NOS staining was relatively more intense than i-NOS staining. In both sham and alcohol-treated groups, e-NOS staining was darker than i-NOS staining. Laminin $\alpha 1$ immunoreactivity was lower in $50 \%$ alcohol-administration group. In sham group; TUNEL staining which demonstrates the apoptosis of the neuroepithelial tissue was very low. However, in alcohol-treated group TUNEL staining was more strong than sham group (Figure 2).

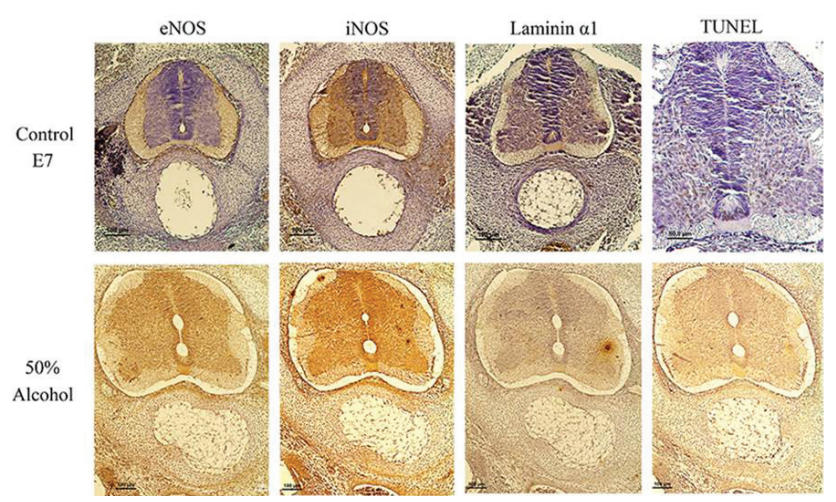

Figure 3. In Sham group, normally closed neural tube, normal medullary cord and developing layers were observed. However, in E7 days ethanol administration group, these structures were disrupted and double spinal cord channel was seen. Bar: $50 \mu \mathrm{m}$ (Control TUNEL), $100 \mu \mathrm{m}$ (Other images).

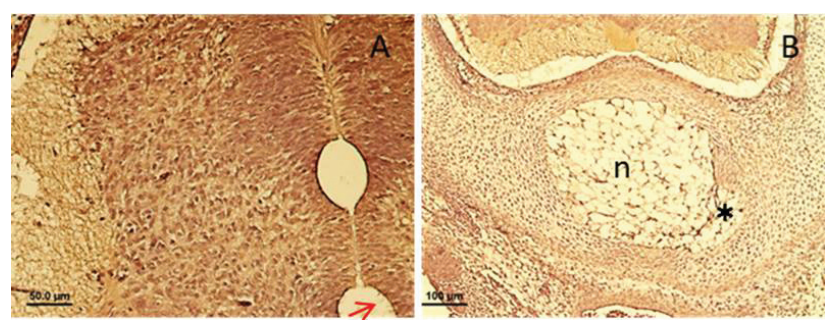

Figure 4. The detail of the E7 alcohol group which showed double channel. One of these channel (A) had cilia (arrow). There was also abnormal (*) notochord (B).
On E7 day of alcohol treated group; varying degrees of disorders were revealed in ventricular layer, motor columns and dorsal root ganglia (DRG). Significant changes were seen at medullary cord maturation center channel, white-gray matter, dorsal, ventral and lateral horns (Figure 3). The main finding of this group was the presence of the double center channel and one of the channels was surrounded by ciliated ependymal cells. Also, deformation at notochord was observed (Figure 4). In sham group, normal basal level of e-NOS and i-NOS staining were present. However, these stainings were more strong in alcohol treated group. We observed that e-NOS staining was relatively higher than i-NOS staining. In both sham-, and alcohol-treated groups, e-NOS staining was darker than i-NOS staining. Laminin immu-

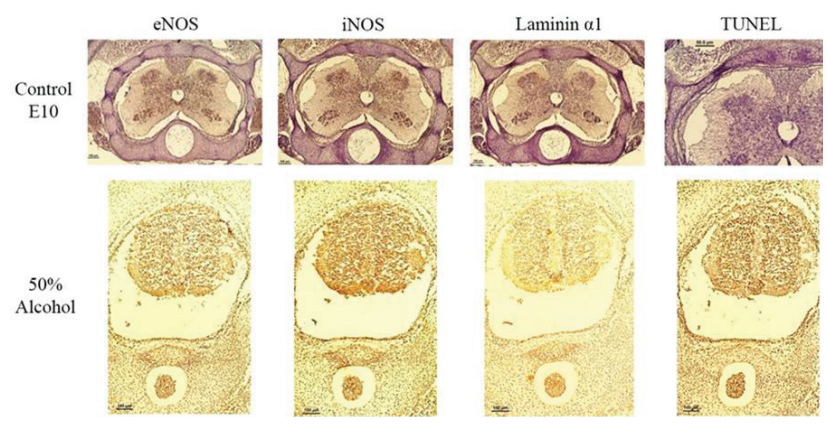

Figure 5. In sham groups, completely normal spinal cord and surrounding structures were seen. However, in E10 days ethanol administration group, these structures were severely disrupted. Bar: $50 \mu \mathrm{m}$ (Control TUNEL), $100 \mu \mathrm{m}$ (Other images).

\section{The effect of alcohol on the secondary neurulation}

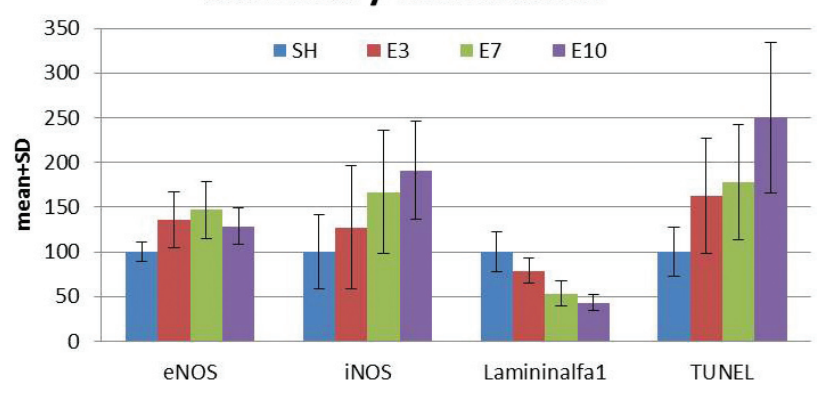

Figure 6. Ethanol administration (E3, E7, E10 days). Immunohistochemistry staining was assessed in a blinded manner with $\mathrm{H}$-score compared to shame ( $\mathrm{SH})$. The percentage of positive apoptotic cells was determined by TUNEL staining. All values were expressed as the percentage of sham. SD: Standart deviation. 
noreactivity was decreased. In addition, apoptotic cells were increased especially in gray matter (Figure 3).

In E10 day of alcohol-treated group; pathology was observed in mantle layer, ventral and dorsal horns of vertebral body, vertebra curves and DRG. The spinal cord and notochord were quite smaller depending on the decrease in the density of cells. Also, we observed that, the spinal cord channel disappeared, cell loss was widely seen, and cells were collected at the edge. Corruption and irregularities were found in the cells. The e-NOS and i-NOS reactivities were increased where i-NOS reactivity was more than e-NOS reactivity. Reactivity of the laminin was increased clearly. Intense apoptosis was observed in the spinal cord and notochord (Figure 5).

Microscopic examination demonstrated that decrease in pathological disorders in E7 day- samples was statistically significant $(\mathrm{p}<0.01)$. However, pathological disturbances were more frequent in E3 and E10 day-samples. iNOS was more frequently seen than eNOS which was statistically significant $(p<0.01)$. iNOS was found more frequently in subsequent days however it was less significant. Laminin expression decreased in following days and this decrease was statistically significant $(\mathrm{p}<0.01)$. Whereas, increase in apoptotic cells were found but it was less significant (Figure 6).

\section{DISCUSSION}

Neurulation is the embryonic process that forms the brain and spinal cord. This process includes the formation of the neural plate, rise of the lateral neural folds, and eventually the fusion of these folds to create the neural tube ${ }^{(17)}$. Secondary neurulation begins with the formation of medullary cord at $\mathrm{HH}$ stage 16 or 51-56 h of incubation. Multiple cavities develop inside the medullary cord. These cavities coalescence to form single lumen, which becomes continuous with the neurocele of the primary neural tube and finally secondary neurulation is completed by $\mathrm{HH}$ stage on $35^{\text {th }}$ or $8^{\text {th }}-9^{\text {th }}$ days of incubation ${ }^{(18)}$.

Several animal models such as chick embryos, Japanese medaka, mice, zebrafish have been used successfully to investigate the effects of ethanol on developing central nervous system ${ }^{(1,18)}$. However, chick embryos, which do not metabolise alcohol to acetaldehyde until day 9 of gestation permits investigating the effects of ethanol in the absence of its primary metabolite. This is the reason why we used chick embryos in this study. In this study the relation between primary and secondary neurulation was shown, experimental analysis on this process was performed morphologically and organizations and behaviors of cells were defined. In optimization experiments, it was observed that $10 \%, 25 \%$ and $50 \%$, alcohol applications caused neural tube defects when applied before neurulation ${ }^{(19)}$. Although there are many studies on the primary stage of neurulation, secondary neurulation which has gained an importance due to its possible role in manipulating neural tube formation is still a mystery. In our study, $50 \%$ ethanol treatment was applied at $50^{\text {th }} \mathrm{h}$ of incubation supposing that this would interrupt or affect secondary neurulation. There was clear effect of alcohol on the secondary neurulation which also affected later development.

In addition to exposure to ethanol and many chemical agents can affect the neural tube development of chick embryos. For example, Lee and Nagele ${ }^{(20)}$ administered local anesthetics under in vivo (100$200 \mu \mathrm{g} / \mathrm{ml})$ and Güney et al. ${ }^{(21)}$ administered diazepam $(400 \mu \mathrm{g} / \mathrm{ml})$ in vitro culture conditions to the chicks at the same developmental stage and found that these caused neural tube defects by affecting microfilament function in neuroepithealial cells. In a study by Greenaway and Fantel ${ }^{(22)}$ rifampin $(100 \mu \mathrm{g} /$ $\mathrm{ml})$ was injected to embryos and it was observed that rifampin impaired the metabolism of cytochrome p450 enzyme and thus caused neural tube defect. Some studies have reported that heavy metals and enviromental pollutants cause defects in neural tube, heart, brain and sensory organs of chick embryos where the most frequent factor FAS $+{ }^{(17)}$.

Ethanol-induced anomalies are closely related to the timing of exposure. Namely, in chick embryos for example, ethanol exposure at early gastrulation through neurulation stages induces cranial defects ${ }^{(24,25)}$. However, exposure at post neurulation stages causes significant growth retardation. In the studies conduc- 
ted using alcohol, cell death was observed in the facial region and neural crest in chick embryos, which caused a loss in the size of chick embryos with growth retardation ${ }^{(26)}$. Moreover, alcohol impairs development, function and life of nerve cells by affecting brain and prevents cell migration ${ }^{(27)}$. In these studies, findings were associated with the dose and duration of alcohol exposure. Similar to these studies, in the present study, growth retardation in all organs, disturbances in the body symmetry, contour distortion and flattening in the facial region were observed macroscopically due to defects in secondary neurulation.

During secondary neurulation, defining two cell groups as central and surrounding cells and observing cavity formation in central cells point out to the importance of the secondary neurulation phase. Relations among central cells having such different cell behaviour show that the factors playing a role in making the cell stay at the centre during migration have a role in the formation of secondary neurulation (28). The fact that cells stop migrating or proliferating, but die to form a cavity for the canal or attach to the developing neural tube increases the importance of such factors. Cell behaviour mentioned here is mediated through different factors such as genetic information, environmental factors, growth factors and adhesion molecules ${ }^{(29)}$. In this study, we determined significant changes at medullary cord maturation, center channel, white-gray matter, dorsal, ventral and lateral horns in E7 embryos. The main finding of this group was the presence of the double center channel and one of the channels was surrounded by ciliated ependymal cells. However, we observed that, the spinal cord channel disappeared in E10 embryos. Therefore, alcohol treatment affected all secondary neurulation processes which induced moderate abnormalies during later stages of development.

It has long been known that developmental defects occur due to increased NOS. In a related study, Ron and colleagues reported that L-N6-(1-iminoethyl)lysine, which is used to inhibit NOS2, reduced the neural tube defects in babies of diabetic mothers. This treatment resulted in alleviation of endoplasmic reticulum stress, decline in apoptosis and reduction in congenital defects ${ }^{(9)}$. Plachta and coworkers noted NTD when apoptosis was inhibited and they attributed this finding to increased NOS as well as inhibition of apoptosis ${ }^{(32)}$. In the present study, increased defects as a result of alterations in NOS immunohistochemistry and concurrent apoptosis were similar to previous studies.

Other factor which is as important as cell behaviours such as migration, proliferation and differentiation ${ }^{(28)}$ in the secondary neurulation of developing embryo is the behaviour of the cell. This behaviour of the cell to produce normal development depends on the ability of the cell to die at the right place, at the right time and in right number besides having an ability to die for orientation. Although the cells have the same nutrition and have no pathological reason to die, there is a programmed cell death leading to cavitation. Cell death occurs at tail bud morphogenesis in chick embryo ${ }^{(31)}$. In terms of cell death and apoptosis, cell formation studies are carried out most commonly on tail region. Tail region incubated between 2-5 days contain many structures along with neural tube, notochord, somits and mesenchyme. The role of cell death is thought to be reshaping embryonic tail ${ }^{(32)}$. Pyknotic nuclei were observed in studies on cell proliferation ${ }^{(33)}$ and cell death was observed at $18^{\text {th }}$ $22^{\text {nd }}$ stages according to $\mathrm{HH}$ stages ${ }^{(12)}$. It was observed based on the appearance of the cells at tail bud morphogenesis and TUNEL staining. Signs of apoptosis at tail bud are mostly observed at medullar cord ${ }^{(31)}$. In our study, in E10 day-embryos, the spinal cord and notochord were quite smaller depending on the decrease in the density of cells. TUNEL staining revealed, disappearance of the spinal cord channel, diffuse, cell loss and accumulation of cells at the edge due to apoptosis. Intense apoptosis was also observed in the spinal cord and notochord.

Extracellular matrix proteins play significant roles in cell growth, cell differentiation, migration, polarization and the formation of basement. Laminin is a matrix molecule which participates in the formation of basement membrane. It also helps organization of epithelial cells and adhesion of these cells to the basement membrane. O'Shea ${ }^{(8)}$ carried out a study on mice and showed that laminin staining was more 
prominent on the neuroepithelium facing the notochord and basement membrane of the side surface. In another study, the researchers noted that laminin staining was weak in neural crest migration region and non-existent in certain regions ${ }^{(34)}$. Their finding is in agreement with our findings. This happens possibly to enable free migration of neural crest cells. Changes in the amount of laminin with time have been shown to affect cell differentiation ${ }^{(11)}$. Sometimes the lumen has been observed to develop even from a cavity. Changes in the presence of laminin with respect to location and time throughout neurulation may be an indicator of its importance in the formation of basement membrane and cell migration. Formation of cavity and lumen by confluence of cavities is coincidental and do not occur in an array ${ }^{(18)}$. In one of the experimental models, small amount of fibronectin and very small amount of laminin have been identified at the distal end of the tail bud in mouse embryos on day 10.5, during the process of secondary neurulation. It has been shown that laminin was present in the lateral aspect of the basement membrane of neuroepithelium but not in the dorsolateral region in an 11 day-old embryo. Presence of copious amounts of fibronectin in these regions on that day has been demonstrated ${ }^{(8)}$. In the present study, we found that immunohistochemical staining of laminin became weaker with development of the embryo and differentiation. Decrease in staining intensity of laminin became more prominent with alcohol application. This can be attributed to the response of the matrix molecules disruptions due to increased oxidative stress.

All of these observations demonstrated that, secondary neurulation is an important step and alcohol caused moderate pathology in this process. These findings point out that, problems are likely to develop during the ongoing life of embryos that affect the quality of life in the future. Ex ovo monitoring and explanation of these effects at the molecular level, will be helpful to understand adverse impacts of alcohol intake on the development.

Acknowledgement: We thank the Celal Bayar University for support of this research thougt grant number 2005/FEF/058.

\section{REFERENCES}

1. Schoenwolf GC, DeLongo J. Ultrastructure of secondary neurulation in the chick embryo. Am J Anat 1980;158:43-63. https://doi.org/10.1002/aja.1001580106

2. Jones KL, Smith DW. Recognition of the fetal alcohol syndrome in early infancy. Lancet 1973;302(7836):999-1001. https://doi.org/10.1016/S0140-6736(73)91092-1

3. Anthony B, Zhou FC, Ogawa T, Goodlett CR, Ruiz J. Alcohol exposure alters cell cycle and apoptotic events during early neurulation. Alcohol Alcohol 2008;43(3):261-73. https://doi.org/10.1093/alcalc/agm166

4. Brüne B. Nitric oxide: NO apoptosis or turning it ON?. Cell Death and Differentiation 2003;10:864-869. https://doi.org/10.1038/sj.cdd.4401261

5. Zhao Z, Eckert RL, Reece EA. Reduction in embryonic malformations and alleviation of endoplasmic reticulum stress by nitric oxide synthase inhibition in diabetic embryopathy. Reprod Sci 2012;19(8):823-31. https://doi.org/10.1177/1933719111434543

6. Peunova N, Scheinker V, Ravi K, Enikolopov G. Nitric oxide coordinates cell proliferation and cell movements during early development of Xenopus. Cell Cycle 2007;6(24):313244.

https://doi.org/10.4161/cc.6.24.5146

7. Ron D, Messing RO. Signaling pathways mediating alcohol effects. Curr Top Behav Neurosci 2013,13:87-126. https://doi.org/10.1007/978-3-642-28720-6_161

8. O'Shea K. Differential deposition of basement membrane components during the formation of the caudal neural tube in the mouse embryo. Development 1987;99:509-519.

9. Zhou L, Li Y, Yue BY. Oxidative stress affects cytoskeletal structure and cell-matrix interactions in cells from an ocular tissue: the trabecular meshwork. J Cell Physiol 1999;180(2):182-9.

https://doi.org/10.1002/(SICI)1097-4652(199908)180:2< 182::AID-JCP6>3.0.CO;2-X

10. Detrait ER, George TM, Etchevers HC, Gilbert JR, Vekemans M, Speer MC. Human neural tube defects: developmental biology, epidemiology, and genetics. Neurotoxicol Teratol 2005;27(3):515-24. https://doi.org/10.1016/j.ntt.2004.12.007

11. Osorio L, Teillet M, Palmeirim I, Catala M. Neural crest ontogeny during secondary neurulation: a gene expression pattern study in the chick embryo. The International Journal of Developmental Biology 2009;53:641-648.

https://doi.org/10.1387/ijdb.072517lo

12. Hamburger V, Hamilto HL. A series of normal stages in the development of the chick embryo. 1951. Dev Dyn 1992;195(4):231- 272. https://doi.org/10.1002/aja.1001950404

13. Özbilgin $\mathrm{K}$, Boz $\mathrm{B}$, Tuğyan $\mathrm{K}$, İnan $\mathrm{S}$, Vatansever $\mathrm{S}$. RHAMM Expression in the Rat Endometrium during the Estrous Cycle and following Implantation. J Reprod Infertil 2012;13(3):131-7.

14. Taneli F, Aydede H, Vatansever S, Ulman C, Ari Z, Uyanik BS. The long-term effect of mesh bioprosthesis in inguinal hernia repair on testicular nitric oxide metabolism and apoptosis in rat testis. Cell Biochem Funct 2005;23(3):213-20. https://doi.org/10.1002/cbf.1139

15. Oktem G, Altay B, Turna B, Aktug H, Yavasoglu A, Yilmaz $\mathrm{O}$ et al. Determination of nitric oxide synthase activity and apoptosis of germ cells in different obstruction models. Acta 
Histochem 2009;111(2):119-26. https://doi.org/10.1016/j.acthis.2007.01.005

16. Yuksel H, Yilmaz O, Karaman M, Firinci F, Turkeli A, Kanik ET, et al. Vascular endothelial growth factor antagonism restores epithelial barrier dysfunction via affecting zonula occludens proteins. Exp Ther Med 2015,10(1):362-368. https://doi.org/10.3892/etm.2015.2502

17. Song G, Cui Y, Han ZJ, Xia HF, Ma X. Effects of choline on sodium arsenite-induced neural tube defects in chick embryos. Food Chem Toxicol 2012;50(12):4364-74. https://doi.org/10.1016/j.fct.2012.08.023

18. Yang HJ, Wang KC, Chi JG, Lee MS, Lee YJ, Kim SK et al. Neural differentiation of caudal cell mass (secondary neurulation) in chick embryos: Hamburger and Hamilton Stages 16-45. Brain Res Dev Brain Res 2003;142(1):31-36. https://doi.org/10.1016/S0165-3806(03)00009-9

19. Aydemir I, Gürcü B. Histochemical Determination of Glycosaminoglycans (GAGs) in Normal and Ethanol-Induced Chick Embryo During Neural Tube Development. African Journal of Biotechnology 2011;10(53):10817-10824. https://doi.org/10.5897/AJB11.918

20. Lee H, Nagele RG. Neural tube defects caused by local anesthetics in early chick embryos. Teratology 1985;31:119-127. PMID: 3920774. https://doi.org/10.1002/tera.1420310114

21. Güney Ö, Selçuki M, Ünlü A, Bağdatoğlu C. The effect of diazepam on the development of neural tube defects in early chick embryos. Turkish Neurosurgery 1999;9:44-47.

22. Greenaway JC, Fantel AG. Enhancement of rifampin teratogenicity in cultured rat embryos. Toxicol Appl Pharmc 1983;69:81-88. PMID: 6857691. https://doi.org/10.1016/0041-008X(83)90122-9

23. Asmatullah SNQ, Shakoori AR. Embryotoxic and teratogenic effects of hexavalent chromium in developing chicks of Gallus domesticus. Environ Cont Toxicol 1998;61:281-288. https://doi.org/10.1007/s001289900760

24. Cartwright MM, Smith SM. Stage-dependent effects of ethanol on cranial neural crest cell development: partial basis forthe phenotypicvariations observed in fetal alcohol syndrome. Alcohol Clin Exp Res 1995;19(6):1454-62. https://doi.org/10.1111/j.1530-0277.1995.tb01007.x

25. Rovasio RA, Battiato NL. Ethanol induces morphological and dynamic changes on in vivo and in vitro neural crest cells. Alcohol Clin Exp Res 2002;26(8):1286-98. https://doi.org/10.1111/j.1530-0277.2002.tb02669.x

26. Ahlgren SC, Thakur V, Bronner-Fraser M. Sonic hedgehog rescues cranial neural crest from cell death induced by ethanol exposure. Develop Biol 2002;99:10476-10481. https://doi.org/10.1073/pnas.162356199

27. Hirai K, Yoshioka H, Kihara M, Hasegawa K, Sawada T, Fushiki S. Effects of ethanol on neuronal migration and neural cell adhesion molecules in the embryonic rat cerebral cortex: A tissue culture stud. Brain Res Dev Brain Res 1999;118:205-210. PMID: 10611520. https://doi.org/10.1016/S0165-3806(99)00159-5

28. Jessell TM, Bovolenta P, Placzek M, Tessier-Lavigne M, Dodd J. Polarity and patterning in the neural tube: the origin and function of the floor plate. Ciba Found Symp 1989;144:255-276. PMID: 2673681.

29. Hay ED. Role of cell-matrix contacts in cell migration and epithelial-mesenchymal transformation. Cell Differ Dev 1990;32:367-375. PMID: 2099239. https://doi.org/10.1016/0922-3371(90)90052-X

30. Plachta N, Traister A, Weil M. Nitric oxide is involved in establishing the balance between cell cycle progression and cell death in the developing neural tube. Exp Cell Res 2003;288(2):354-62. https://doi.org/10.1016/S0014-4827(03)00215-5

31. Miller SA, Briglin A. Apoptosis Removes Chick Embryo Tail Gut and Remnant of the Primitif Streak. Dev Dyn 1996;206:212-218. PMID: 8725288. https://doi.org/10.1002/(SICI)1097-0177(199606)206:2 $<212::$ AID-AJA $10>3.0 . \mathrm{CO} ; 2-4$

32. Schoenwolf GC. Morphogenetic processes involved in the remodeling of the tail region of the chick embryo. Anat Embryol (Berl.) 1981;162:183-197. DOI: $10.1007 / \mathrm{BF} 00306490$. https://doi.org/10.1007/BF00306490

33. Miller SA, Monoson T, Tignor J. Cell proliferation in endoderm epithelium during early morphogenesis of chick embryo hindgut. FASEB J 1994;8:A925.

34. Mataya LA. Formation of the neural tube epithelium basement membrane during secondary neurulation in the chick embryo. Thesis. 2010. 